|Araştırma Makalesi / Research Article |

\title{
Haydar Kazgan'ın Ekonomi Tarihi Çalışmaları Işığında Tarih Ders Kitaplarının İncelenmesi ${ }^{1}$ \\ Examination of History Textbooks in The Light of Economic History Studies of Haydar Kazgan
}

\section{Hayati Adalar ${ }^{2}$}

\section{Anahtar Kelimeler Haydar Kazgan, \\ tarih ders kitapları, ekonomi tarihi, karşılaştırma}

\section{Keywords Haydar Kazgan, history textbooks, economic history, comparison}

Başvuru Tarihi/Received 04.03.2020

Kabul Tarihi /Accepted 23.04.2020

\section{Öz}

Bu araştırmanın amacı cumhuriyet tarihinin önemli ekonomi tarihi profesörlerinden biri olan Haydar Kazgan'ın ekonomi tarihi kapsamında yaptığı çalışmalarında ortaya koyduğu görüşleri bağlamında ülkemizdeki mevcut lise tarih ders kitaplarının incelenmesidir. Araştırmada nitel araştırma deseni takip edilmiş olup, doküman incelemesi yöntemine başvurulmuştur. Verilerin analizinde ise içerik analizine başvurulmuştur. Bu çerçevede öncelikle Haydar Kazgan'ın mevcut çalışmaları incelenmiştir. Böylelikle yazarın ekonomi tarihi çalışmaları kapsamında yoğunlukla tartıştığı 8 adet tarihi olay ve kurum listelenmiştir. Bunlar "Kapitülasyonlar, Yeniçeri Ocağının Kaldırılması, Düyûn-ı Umûmiye, Osmanlı Bankası, 1877-78 OsmanlıRus Savaşı, Galata Bankerleri, Gedikler ve İç ve Dış Borçları"dır. Sonraki aşamada ise bu olayların lise tarih ders kitaplarında nasıl verildiği, olayların ekonomi ile ilişkisinin nasıl yansıtıldığı Haydar Kazgan’ın görüşleri çerçevesinde karşılaştırmalı olarak incelenmiş ve tartışılmıştır. Araştırmada elde edile bulgular, karşılaştırmalı olarak incelenen 8 olay ve kuruma ilişkin sunulan yorum, tespit, değerlendirme ve ilişkilendirmeler bağlamında, lise tarih ders kitapları ile Haydar Kazgan'ın ekonomi ve finans tarihi çalışmaları arasında önemli farklılıkların olduğunu ortaya koymuştur. Bu araştırma lise tarih ders kitaplarında ele alınan bu tarihi olay ve kurumların ekonomi disiplininin temel anlayışı çerçevesinde incelenmesinin bu konuların daha doğru ve bilimsel bir şekilde anlaşılması ve yorumlanmasına katkı sağlayabileceğini ortaya koymaktadır. Araştırma ülkemizde halihazırda okutulan lise tarih ders kitaplarının okuyucuya tarih öğretimi amacıyla ekonomi eksenli bir bakış açısı sunma konusunda daha da geliştirilmesi gerekliliğine dikkat çekmektedir.

Abstract

The aim of this research is to examine existing high school history textbooks in our country in the context of the views put forward by Haydar Kazgan, one of the important professors of economic history of the republic's history, within the context of economic history. In this research, qualitative research design was followed and document analysis method was applied. In the analysis of the data, content analysis was used. Within this framework, firstly the present studies of Haydar Kazgan are examined. Thus, 8 historical events and institutions that the author has discussed extensively within the scope of his economic history studies are listed. These are "Capitulations, Removal of the Janissary, The Ottoman Public Debt, Ottoman Bank, 187778 Ottoman-Russian War, Galata Bankers, Gedikler, Ottoman Internal and External Debts. In the next stage, it is examined and discussed comperatively, with in the frame of Haydar Kazgan's views, how these events are presented in high school history books and how these events are reflected in the economy. In the context of the comments, determinations, evaluations and associations presented for 8 events and institutions examined comparatively; findings obtained in the study reveal that there are important differences between high school history textbooks and Haydar Kazgan's studies on economic and financial history. This study reveals that examining these historical events and institutions in high school history books within the framework of the basic understanding of economic discipline may contribute to a more accurate and scientific understanding and interpretation of these historical events and institutions. The research draws attention to the need to further develop high school history textbooks currently being taught in our country in order to offer the reader an economics-oriented perspective for teaching history.

\footnotetext{
${ }^{1}$ Bu çalışmanın bir bölümü 10-12 Ekim 2019 tarihleri arasında Bolu'da düzenlenen Vı. Uluslararası Tarih Eğitimi Sempozyumu'nda sözlü bildiri olarak sunulmuştur.

${ }^{2}$ Manisa Celal Bayar Üniversitesi, Eğitim Fakültesi, Sosyal Bilgiler Eğitimi Anabilimdalı, Manisa, TÜRKiYE; https://orcid.org/0000-0002-6083-1055
} 


\section{Introduction}

It can be said that the use of economics discipline in history teaching or following a history teaching approach integrated with the economy within the framework of basic approaches of the economy is a good method that can be followed within the framework of an interdisciplinary understanding of history teaching. The aim of this study is to compare the views of one of the important professors of economics and finance history of the republican history, Haydar Kazgan's studies in the context of the history of economics and finance and the current high school history textbooks in our country. Within the scope of the research, 8 events and institutions which are mostly overshadowed by political, military and administrative justifications and which are believed to be better understood when discussed in terms of their economic and financial aspects are discussed. These events and institutions were tried to be examined comparatively in the textbooks and in the context of the findings and evaluations that Kazgan made in the relevant studies.

\section{Method}

In the research, qualitative research design was followed and document analysis method was applied. In the study, it was decided to follow such a method as the purpose was examined in the current form of how the reflected subjects were reflected both in high school history textbooks and related studies of Haydar Kazgan. The documents used in the study are the history textbooks "10th and 11th Grade History; 12th Grade T.C. Revolutionary History and Kemalism Textbooks" which officially taught in high schooleducation institutions in our country during the 2019-2020 academic year and Kazgan's work on the history of the Ottoman economy and finance. In the analysis of the documents, descriptive analysis technique was used. The 8 historical events and institutions that were subjected to comparative analysis in the research also reflect the themes related to descriptive analysis. These themes; "1.Capulations, 2.Removal of the Janissary, 3.The Ottoman Public Debt, 4. Ottoman Bank, 5.1877-1878 OttomanRussian War, 6.Galata Bankers, 7.Gedikler and 8.Otman Internal and External Debts. Within the scope of the research, descriptive analysis technique was used in the analysis of the examined documents. The 8 historical events and institutions that constitute the main problem of the research and undergo comparative analysis also reflect the themes related to descriptive analysis.

\section{Result and Discussion}

The findings of the study reveal that there are significant differences between high school history textbooks and Haydar Kazgan's studies in the history of economics and finance in the context of the interpretations, determinations, evaluations and associations presented in relation to 8 events and institutions examined comparatively. It was concluded that the basic concepts of economics discipline were not sufficiently utilized in the teaching of historical events and institutions in high school history textbooks and that the textbooks were insufficient to provide an economic-oriented perspective to the reader.

From the 8 themes examined in the high school history textbooks, it is understood that only the Capitulations, The Otman Internal and External Debts and The Ottoman Public Debt subjects are reflected in a relatively sufficient and acceptable extent in terms of economic reasons and results. However, The Removal of the Janissary, The Galata Bankers, Ottoman Bank, The Gediks and The 1877-78 Ottoman-Russian War were either not adequately covered or limited in the context of individuals, events, and chronology, independent of an economic perspective. On the other hand, Kazgan's related studies have concluded that all 8 themes examined in detail and systematically in terms of economic and financial aspects, cause, effect, actor and indirect impact. This reveals that these historical events and institutions, which are discussed extensively in the textbooks, are handled far from the economic and financial context that Haydar Kazgan follows in addressing the same issues and within the framework of a limited economic and financial cause and effect relationship. For example, the issue of Capitulations, which are discussed extensively in textbooks, is far from giving the reader the opportunity to establish a context for the economic and financial collapse of the Ottoman Empire. However, it seems that Kazgan's handling of the same subject is quite different from this vicious understanding in the textbooks. It can be said that Kazgan's evaluations that the capitulations have turned into a financial exploitation tool for the economic weakening of the Ottomans by Western states can be said to summarize the many accents in the textbooks. Another example is the Ottoman Bank. It was seen that there was a very insufficient content in the high school history textbooks on the Ottoman Bank. On the other hand, it can be said that Kazgan deals with the positive and negative aspects in many respects. Kazgan pointed out that the Ottoman Bank prevented the government from exercising its seigniorage right and how it became a debt swamp and how the past was mixed with market and financial games.

Economics is the missing link of effective history teaching. History can be misunderstood if interpreted with a lack of economic perspective. As Haydar Kazgan emphasizes in his studies, the reflection of the economy-centered thinking approach in history textbooks can be an important step in completing this missing link. The analytical history interpretation provided by Haydar Kazgan in the study of history of economics and finance may be a correct starting point in pursuing an integrated historical narrative that adopts an economy-centered thinking approach in effective teaching of history subjects at different levels, especially in high school education. 


\section{GíRiş}

Sosyal bilimlerin en önemli dallarından birini teşkil eden tarih biliminin sosyal bilimlerle çok yakın bir ilişkisi bulunmaktadır. En başta tarih'in bir sosyal bilim olması ve diğer sosyal sosyal bilimler gibi ortak bazı problemlere ve metodolojiye sahip bulunması yönüyle diğer sosyal bilimlerin etkili öğretimine de katkı sağlayacağı düşünülmüştür. Diğer yandan özellikle modern tarih öğretimi anlayışı ile birlikte tarih öğretiminde "iktisat, sosyoloji, psikoloji, hukuk vb." diğer sosyal bilim disiplinlerinden de etkin bir şekilde yararlanabileceği anlayışı da kabul görmeye başlamıştır. Bir anlamda sosyal bilimlerin aynı olayları benzer araştırma teknikleriyle ele alıp incelemesi yönüyle bütüncül bir tarih öğretimi için bu disiplinlerin metot ve kavramlarından yararlanılması oldukça önemli bir konu olarak karşımıza çıkmaktadır.

Tarihsel olguları, yerleşmiş açıklamalar ve peşin hükümlerle değerlendirmenin kolaylığı yaygın bir kabule yol açmaktadır. Bunlar kuşaktan kuşağa tekrarlanabilir; araya yeni nüanslar ve komplo teorileri eklenerek zenginleştirilebilir. Oysaki Osmanlı tarihini, tarihi kişiler ve birtakım askeri ve siyasal olaylar etrafında yüzeysel bir tarzda incelemek yerine, o dönemde uluslararası iktisadi ilişkilere yön veren daha derindeki çıkar hesaplarını esas alan ve gelişmelerin arkasındaki gerçek iktisadi nedenleri arayan bir yaklaşımla değerlendirmek daha doğru bir yaklaşım olabilir (Tokdemir, 2011).

Tarihi olay ve olguları ekonomik ve finansal bağlamda ele almanın önemli gerekçeleri ortaya konulabilir. Bunlardan biri örneğin Tokdemir'e (2011) göre Kapitalizminin tarihinde özellikle 19. yüzyılın ikinci yarısından bu yana uluslararası ilişkileri, savaşları, siyasal ve ekonomik gidişatı, finans konularını gündeme getirmeden doğru biçimde değerlendirmenin mümkün olamamasıdır. Yazar Osmanlı Devleti'nin son seksen/yüz yılının buna iyi bir örnek olduğuna dikkat çekmektedir.

Tarihi olayların daha derinlemesine anlaşılabilmesi için olayların ekonomik ve finansal arka planıyla irdelenmesi gerekmektedir. Tarihi olayları anlamda ekonomi disipline başvurmak oldukça önemlidir. Bir başka ifadeyle tarih öğretiminde ekonomi merkezli düşünme yaklaşımına başvurulması öğrencilerin tarihi olay, olgu ve kurumları daha derinlemesine analiz edebilmelerine fırsat tanımaktadır. Günümüzde birçok farklı disiplinin öğretiminde olduğu gibi tarih öğretiminde de disiplinlerarası yaklaşım ve uygulamalara başvurulması oldukça önemlidir.

Tarih öğretiminde ekonomi disiplininden yararlanılması ya da ekonominin temel yaklaşımları çerçevesinde ekonomi ile entegre bir tarih öğretim anlayışının takip edilmesinin, disiplinlerarası bir tarih öğretimi anlayışı çerçevesinde takip edilebilecek iyi bir metot olduğu söylenebilir. Bu bağlamda Niederjohn, Schug ve Wood (2013) ekonominin tarihe entegre edilmesinin iki temel kategoride öğrenmeye yardımcı olabileceğine dikkat çekmişlerdir: Birincisi, tarihi olayların doğru şekilde anlaşılabilmesi, ekonominin temel kavramlarının da işe koşulmasını gerekli kılmaktadır. Örneğin "para politikası, maliye politikası ve uluslararası ticaret gibi”. i̇kincisi ise, ekonomi, öğrencilerin tarihi olayları yorumlarken 'olgu, olay, yer, zaman' karmaşasından kurtularak bu verileri öncelik sırasına koyabilecek bir analitik düşünme becerisini ve etkin karar vericiler olarak bireylerin bu süreçteki etkin rolünü fark etmelerine katkı sağlamaktadır (s.103-104).

Bu bağlamda ülkemizde okutulan lise tarih ders kitaplarında yer verilmiş olan ve ekonomik bağlamda önemli faktörler barındıran bazı tarihi olay ve kurumları ekonomik bir perspektiften ela alma konusunda özellikle Osmanlı ekonomi ve finans tarihi konusunda önemli çalışmalar yürütmüş olan Haydar Kazgan'ın eserlerinden yararlanmak oldukça yerinde olabilir. Bu gerekçeyi daha iyi ortaya koymak adına Haydar Kazgan ve ekonomi tarihi çalışmaları hakkında bilgi vermek yerinde olacaktır.

\section{Haydar Kazgan ve Ekonomi Tarihi Çalışmaları}

Haydar Kazgan 1921'de İstanbul'da doğmuştur. 1941'de İtalyan Lisesi'ni, 1943 'te Ankara Gazi Eğitim Enstitüsü Fransızca Bölümü'nü, 1950'de de İstanbul Üniversitesi İktisat Fakültesi'ni bitirmiştir. 1952'de İstanbul Teknik Üniversitesi İktisat Kürsüsü'ne asistan olan Kazgan, 1955 'te doktorasını tamamlayarak Chicago Üniversitesi'ne doçentlik eğitimine gitmiştir. 1961'de doçent, 1966'da profesör olan Haydar Kazgan emekli olduğu 1988 yılına kadar i.T.Ü İşletme Fakültesi'nde öğretim üyeliği yapmıştır. İstanbul Üniversitesi İktisat Fakültesi'nde "Osmanlı Finansı" konusunda doktora ve master çalışmaları yapmıştır.

Kazgan'ın, bilimsel çalışma alanları arasında yer alan Finans Tarihi gibi bir konuya yönelmesinde ve hatta bu alanda Türkiye'de Finans Tarihi alanının önde gelen isimlerden biri olmasında, belki bir ölçüde işletme iktisadı geleneğinin etkisinin olduğu kabul edilebilir. Tarihe olan yakın ilgisi sebebiyle, Kazgan uzun yıllar iTü’de İnkılâp Tarihi dersleri de vermiştir (Günçavdı, 2018).

Düne oranla daha karmaşık olan olayları, daha karmaşık ve özelleşmiş analiz araçlarıyla anlamaya çalışmak yanında, bilinen konuları yeni bir yaklaşım ve metodolojinin ışığında açıklamak gerekiyor. Prof. Dr. Haydar Kazgan, bilimsel yaklaşımı ve analitik bakış açısı ile tarihsel bir konunun, bir sorunun diğer aydınlar ve bilim insanları tarafından dikkate alınmayan evrelerini, yönlerini bir sorun olarak, bir analiz unsuru olarak dikkate almakta ve yansıtmaktadır (Tokdemir, 2011: 17).

\section{Araştırmanın Amacı}

Tarih ders kitaplarında, daha çok savaşlar, fetihler, toprak kazançları ve kayıpları, yapılan antlaşmalar gibi konular sıklıkla yer aldığı halde finansal konulara çok yer verilmemektedir. Bu durum da bireylerin temel tarih bilgisi kaynakları açısından, kendilerine merak kapısı açacak bir alandan yoksun kalarak yetişmelerine neden olmaktadır. Esasında Osmanlı finans tarihi savaşlarla parçalanan ülkede, onun tamamlayıcısı olarak ortaya çıkan finans oyunlarının tarihidir (Kazgan, 2011: 9-12). Dolayısıyla tarih ders kitaplarıyla teknik ayrıntı olarak bilinen bu ilişki iyi şekilde yansıtılabilirse tarihi olayların sebep ve sonuçlarının daha iyi anlaşılması sağlanabilir. 
Bu araştırmanın amacı cumhuriyet tarihinin önemli ekonomi ve finans tarihi profesörlerinden biri olan Haydar Kazgan'ın Osmanlı Devleti'nin dağılma ve yıkılış devri (1792-1918) ile Türkiye Cumhuriyeti'nin kuruluşundan 1960'lara kadarki dönemine ait ekonomi ve finans tarihi kapsamında yaptığı çalışmalarında ortaya koyduğu görüşleri bağlamında ülkemizdeki mevcut lise tarih ders kitaplarının incelenmesidir. Araştırmada lise tarih ders kitaplarında çoğunlukla siyasi, askeri ve idari gerekçelendirmelerin gölgesinde kalan ve esasında ekonomik ve finansal yönleriyle de tartışıldığında daha iyi anlaşılabileceğine inanılan bazı olay ve kurumlar ele alınmıştır. Bu olay ve kurumlar hem ders kitaplarında hem de Haydar Kazgan'ın ilgili çalışmalarında yaptığı, tespit ve değerlendirmeler bağlamında karşılaştırmalı olarak incelenmeye çalışılmıştır. İncelen bu olay ve kurumlara ilişkin bilgi araştırmanın yöntem bölümünde açıklanmıştır.

\section{YÖNTEM}

\section{Araştırma Modeli}

Araştırmada nitel araştırma deseni takip edilmiş olup, doküman incelemesi yöntemine başvurulmuştur. Bilindiği gibi nitel araştırmalar, gözlem, görüşme ve doküman analizi gibi nitel veri toplama yöntemlerinin kullanıldığı, algıların ve olayların doğal ortamda gerçekçi ve bütüncül bir biçimde ortaya konmasına yönelik nitel bir sürecin izlendiği araştırmalardır (Yıldırım ve Şimşek, 2013: 45). Birçok araştırma yönteminin tamamlayıcısı olarak kullanılan doküman analizi, basılı veya elektronik belge/dokümanlardan anlam çıkarma, anlayış geliştirme ve araştırmaya dayalı bilgiye ulaşma amacıyla da tek başına sistematik bir prosedür olarak kullanılabilir (Bowen, 2009; Corbin ve Strauss, 2015). Araştırmada amaç gerek lise tarih ders kitaplarında gerekse Haydar Kazgan'ın ilgili çalışmalarında karşılaştırmalı olarak incelenen konuların nasıl yansıtıldığı mevcut şekliyle irdelendiği için böyle bir yöntemin takip edilmesi kararlaştırılmıştır. Araştırmada başvurulan dokümanlar, ülkemizde 2019-2020 eğitim ve öğretim döneminde lise kurumlarında resmi olarak okutulan 10. ve 11. sınıf Tarih ile 12. sınıf T.C. İnkılap Tarihi ve Atatürkçülük ders kitapları ve Prof. Dr. Haydar Kazgan'ın Osmanlı ekonomi ve finans tarihi konusunda yapmış olduğu başta “Galata Bankerleri ve Osmanlı'da Avrupa Finans Kapitali" adlı eserleri olmak üzere ilgili tüm çalışmalarından oluşmaktadır.

\section{Veri Toplama Araçları}

Araştırma kapsamında Lise Tarih ve T.C. ITA ders kitapları ile araştırmaya konu olan Haydar Kazgan'ın iktisat tarihi konulu kitap ve makale bibliyografyasından seçilmiş olan çalışmalar incelenmiştir. Haydar Kazgan'ın ilgili çalışmalarından başvurulan dokümanlar kaynakça bölümünde paylaşılmış olduğundan bu bölümde sadece başvurulan ders kitaplarına ilişkin bilgilere yer verilmiştir. Araştırma kapsamında doküman incelemesi yapılan ders kitaplarına ilişkin bilgiler Tablo 1'de paylaşılmıştır.

Tablo 1. Araştırma kapsamında incelenen lise tarih ders kitapları

\begin{tabular}{|c|c|c|c|}
\hline İncelenen Ders Kitabı & Kitabın Kapak Görseli & Kitabın Künyesi & Kitap Hakkında Diğer Bilgiler \\
\hline $\begin{array}{l}\text { 10. Sınıf Lise Tarih Ders } \\
\text { Kitabı }\end{array}$ & 10 & $\begin{array}{c}\text { Yılmaz, A. (2019). Lise Tarih 10. Sınıf, Ders } \\
\text { Kitabı, Illke Basım Yayım, Ankara. }\end{array}$ & $\begin{array}{c}\text { Baskı adedi: Belirsiz } \\
\text { Sayfa sayısı: } 208 \\
\text { Kronoloji: } 11 . y y-1595 \\
\text { Ekonomi konulu kaynak sayısı: } 4\end{array}$ \\
\hline $\begin{array}{l}\text { 10. Sınıf Lise Tarih Ders } \\
\text { Kitabı }\end{array}$ & TARIHTO & $\begin{array}{l}\text { Yüksel E, vd. (2019). Lise Tarih 10. Sınıf, Ders } \\
\text { Kitabı, Devlet Kitapları 2. Baskı. MEB. Ankara }\end{array}$ & $\begin{array}{c}\text { Baskı adedi: } 216.808 \\
\text { Sayfa sayısı: } 224 \\
\text { Kronoloji: } 11 . y y-1595 \\
\text { Ekonomi konulu kaynak sayısı: } 10\end{array}$ \\
\hline $\begin{array}{l}\text { 11. Sınıf Lise Tarih Ders } \\
\text { Kitabı }\end{array}$ & & $\begin{array}{l}\text { Yüksel E, vd. (2019). Lise Tarih 11. Sınıf, Ders } \\
\text { Kitabı, Devlet Kitapları 1. Baskı. MEB. Ankara }\end{array}$ & $\begin{array}{c}\text { Baskı adedi: } 1.051 .835 \\
\text { Sayfa sayısı: } 244 \\
\text { Kronoloji: } 1595-20 . \text { yy } \\
\text { Ekonomi konulu kaynak sayısı: } 40\end{array}$ \\
\hline $\begin{array}{l}\text { 12. Sınıf Lise Türkiye } \\
\text { Cumhuriyeti İnkılap Tarihi } \\
\text { ve Atatürkçülük Ders } \\
\text { Kitabı }\end{array}$ & $\frac{80}{16}$ & $\begin{array}{c}\text { Çevik, A., Koç, G. ve Şerbetçi, K. (2019). Lise } \\
\text { Türkiye Cumhuriyeti Inkılap Tarihi ve } \\
\text { Atatürkçülük 12, Ders Kitabı, Devlet Kitapları } \\
\text { 2. Baskı. MEB. Ankara. }\end{array}$ & $\begin{array}{c}\text { Baskı adedi: } 177.623 \\
\text { Sayfa sayısı: } 273 \\
\text { Kronoloji: } 19 . y y-2016 \\
\text { Ekonomi konulu kaynak sayısı: } 3\end{array}$ \\
\hline
\end{tabular}

\section{Verilerin Analizi}

Araştırma kapsamında incelenen dokümanların analizinde betimsel analiz tekniğine başvurulmuştur. Betimsel analiz yaklaşımında veriler araştırma sorularının ortaya koyduğu kategorilere göre organize edilir ve doğrudan alıntılara çok sık yer verilir (Corbin \& Strauss, 2015). Araştırmanın temel problemini oluşturan ve karşılaştırmalı incelemeye tabi tutulan 8 tarihsel olay ve kurum aynı zamanda betimsel analize ilişkin temaları yansıtmaktadır. Bu temalar Haydar Kazgan'ın Osmanlı Devleti'nin ekonomi ve finans tarihi kapsamında mevcut çalışmaları incelenerek yoğunlukla tartıştığı konulardan yola çıkılarak belirlenmiştir. Araştırmada dokümanlar incelenirken dikkate alınan bu temalar; "1.Kapitülasyonlar, 2.Yeniçeri Ocağının Kaldırılması, 3.Düyûn-ı Umûmiye, 4.Osmanlı Bankası, 5.1877-1878 Osmanlı-Rus Savaşı, 6.Galata Bankerleri, 7.Gedikler ve 8.Osmanlı İç ve Dış Borçları”dır. 


\section{BULGULAR}

Bu bölümde temalara ilişkin bulgular sekiz ayrı başıı altında sunulmuştur. Bulgular, tablo ile sadeleştirilmeye çalışıldıktan sonra ilgili bulgulara ilişkin kaynak metinlere yönelik doğrudan atıflar ve değerlendirmeler ile de desteklenmeye çalışımıştır.

\section{Kapitülasyonlar Temasına İlişkin Bulgular}

Araştırmanın ilk teması olan Kapitülasyonlar konusunun lise tarih ders kitaplarında oldukça detaylı bir şekilde ele alındığı söylenebilir. Kapitülasyonlar konusu Osmanlı Devleti'nin siyasi ve ekonomik tarihinde ilk gündeme geldiği dönem dikkate alındığında konuya 10. sınıf tarih ders kitaplarında da yer verildiği görülmektedir. Diğer yandan konunun araştırma problemini ilgilendiren boyutuyla ele alınmasının 11. ve 12. sınıf ders kitaplarında gündeme geldiği görülmektedir. Özellikle 11. sınıf tarih ders kitabında Kapitülasyonlar konusunun iki ayrı ünitede ekonomik ve siyasi boyutları başta olmak üzere birçok açıdan irdelenmiş olduğu dikkati çekmektedir. Bu bağlamda Kapitülasyonlar temasına ilişkin araştırma bulgularına Tablo 2'de yer verilmiştir.

Tablo 2. Kapitülasyonlar temasına ilişkin betimsel bulgular

\begin{tabular}{|c|c|c|}
\hline Kaynaklar & Bulgular & Bulgu Tespit Edilen Ders Kitapları \\
\hline $\begin{array}{l}\text { Ortaöğretim Tarih } \\
\text { Ders Kitapları }\end{array}$ & $\begin{array}{l}\text { Ekonomik: } \\
\text { Osmanlı toprakların Avrupa için hammadde kaynağı ve pazar haline gelmesi; } \\
\text { - Yerli sanayinin çökmesi. } \\
\text { - Sanayileşme politikalarının başarısız olması. } \\
\text { Yabancı tüccarlara sürekli imtiyazlar tanınması; } \\
\text { - Gayrimüslim tüccarların tekel oluşturması. } \\
\text { - Demiryolları imtiyazlarının Osmanlı ekonomisin çökmesindeki etkisi. } \\
\text { Siyasi (Ekonomik) } \\
\text { Avrupa devletlerinin; } \\
\text { - Daha fazla imtiyaz hakkı almak için Osmanlı’ya baskı kurması. } \\
\text { - Kapitülasyonları kullanarak Osmanlı'ya her konuda müdahale etmesi. } \\
\text { - Ekonomide tam bağımsızlığa aykırı görülmesi. }\end{array}$ & $\begin{array}{l}\text { 11. Sınıf (MEB yay./2. ve } 5 . \\
\text { üniteler) } \\
\text { 12. Sınıf (MEB yay./2. ünite) }\end{array}$ \\
\hline $\begin{array}{l}\text { Haydar Kazgan’ın } \\
\text { İlgili Çalışmaları }\end{array}$ & $\begin{array}{l}\text { Ekonomik: } \\
\text { - Finansal sömürü aracı. } \\
\text { - Yabancı tüccarlara tanınan imtiyazlar. } \\
\text { - Müslim ve Gayrimüslim tebaa arasındaki sosyal ve iktisadi yaşam standartları } \\
\text { farklııı̆ı. }\end{array}$ & \\
\hline
\end{tabular}

Tablodan da anlaşılacağı üzere Osmanlı tarihinde Kapitülasyonları konusu ekonomik boyutuyla -neden, sonuç, aktör ve dolaylı etki- bağlamında detaylıca işlendiği söylenebilir. Ders kitaplarında bu konunun özellikle "Osmanlı topraklarının Avrupa için hammadde kaynağı ve pazar haline gelmesi” bağlamında ele alındığı ve Osmanlı ekonomisi ve yerli sanayisi açısından önemli sorunlara yol açtığına dikkat çekildiği görülmüştür. Bu konuya bir örnek olarak ilgili ders kitabında şöyle bir metin yer almaktadır (Yüksel, 2019b):

“XVIII. yüzyıla kadar bu imtiyazların Osmanlı ekonomisine olumsuz etkisi olmamıştır. Ancak bu yüzyıldan itibaren Avrupa devletleri daha fazla hak ve imtiyaz almak için Osmanlı Devleti'nin üzerinde baskı kurmaya başlamıştır. Osmanlı Devleti'nin zayıflamasıyla birlikte, kapitülasyonların karakterini değiştiren Avrupalılar için Osmanlı toprakları hammadde kaynağı ve pazar hâline gelmiştir. Bu durum yerli sanayiyi baltalamış, gayrimüslim Osmanlı tebaası yabancı devletlerin himayesine girerek Müslüman tüccarlara karşı tekelci özellikler kazanmıştır" (s.65).

Ders kitaplarında Kapitülasyonlar konusunun "Yabancı tüccarlara sürekli imtiyazlar tanınması" bağlamında da sıklıkla ele alındığı ve büyük sermaye sahipleri olan gayrimüslimlerin, bu imtiyazlar sayesinde tek yönlü bir kazanç elde ettiği ve Osmanlı ekonomisinin gelişmesinin önünü tıkadıklarına dikkat çekildiği görülmüştür. Bu konuya bir örnek olarak ilgili ders kitabında şöyle bir metin yer almaktadır (Yüksel, 2019b):

"Yabancı tüccarlara sürekli imtiyazlar tanınması, sermayenin büyük bir kısmının sadece bu ellerde (gayrimüslimlerde) toplanmasına sebep olmuştur." “...Bu gelişmeler neticesinde Osmanlı'da, Avrupa devletlerinde olduğu gibi ulusal sanayi, gelişme imkânı bulamamıştır" (s.194).

Aynı konuya bir diğer ders kitabında da değinildiği dikkati çekmektedir: "Kapitülasyonlar, Osmanlı'da yerli sanayinin kurulmasını önlemişti" (Çevik, Koç, ve Şerbetçi, 2019: 127).

Ders kitaplarında birçok yönüyle yoğun şekilde işlenen Kapitülasyonlar konusuna Haydar Kazgan'ın, ilgili çalışmalarında benzer vurgularla dikkat çektiği söylenebilir. Bir diğer ifadeyle tarih ders kitaplarıyla Kazgan'ın ekonomi tarihi çalışmalarında Kapitülasyonlar konusunda birbirini destekleyen vurguların işlendiği söylenebilir. Ancak ders kitaplarında yer alan bu söylemlerden farklı olarak, Haydar Kazgan'ın Kapitülasyon'ların, Batılı devletlerce (Düvel-i Muazzama) Osmanlı'yı ekonomik olarak zayıflatmaya yönelik bir "Finansal Sömürü Aracı" olarak kullanıldığına vurgu yapması dikkate değer bulunmuştur. Kazgan Kapitülasyonlar ile yabancı tüccarlara tanınan imtiyazlar karşısında yerli tüccar ve esnafın iflas etmesine de dikkat çekmiştir. Bu konuya bir örnek olarak ilgili çalışmasında şöyle bir metin yer almaktadır (Kazgan, 2005): 
“...Yabancılara mülkiyet hakkının verilmiş olması dolayısıyla, bunlar kapitülasyonlardan da istifade ederek, memleketin önemli pazarlama faaliyetlerini tekellerine almışlardı. Yabancı sermaye, pazarlama kesimine de el atmış ve Beyoğlu hatta Sultanhamamı ve Sirkeci'de yabancı perakendeci pazarlayıcı kuruluşlar büyük mağazalar açmışlardı. Durum İzmir'de, Trabzon'da hatta Halep ve Şam'da da aynı idi. Yerli tüccar ve esnaf \%20'den dahi kredi bulamazken, yabancı pazarlayıcı firmalar \%5'ten kredi bulabiliyorlardı" (s.75).

Haydar Kazgan'ın Kapitülasyonlar konusunu Osmanlı toplumu üzerindeki dolaylı etkileri bağlamında işleyişi de bir başka dikkati çeken bulgu olmuştur. Kazgan ilgili çalışmasında; "Türk toplumunun iktisadi yaşamını bütün ayrıntıları ile tahlil etmeksizin, Kapitülasyonları geri kalışımızın esaslı bir açıklama unsuru olarak sayılamayacağına” vurgu yapmaktadır (Tokdemir, 2011). Örneğin aynı dönemde Edirne'ye bağlı bir köyde yaşayan Türk ve Bulgar tebaanın sosyal, iktisadi ve eğitim olanaklarının karşılaştırılmasını Kapitülasyonların değerlendirilmesine ilişkin analizlerinin hareket noktasına yerleştirmesi dikkati çekmektedir.

\section{Yeniçeri Ocağının Kaldırılması Temasına İlişkin Bulgular}

Yeniçeri Ocağının Kaldırılması konusuna lise tarih ders kitaplarında sadece 11. sınıfta yer yerildiği görülmüştür. Diğer yandan 11. Sınıf ders kitaplarında bu konunun özellikle ocağın bozulması, devlet için önemli sorun haline gelişi ve ocağın lağvedilmesinin "Vaka-yı Hayriye" olarak isimlendirilmesiyle hayırlı bir gelişme olarak kabul görüldüğü üzerinde etraflıca durulduğu dikkati çekmektedir. Yeniçeri Ocağının Kaldırılması temasına ilişkin araştırma bulgularına Tablo 3’te yer verilmiştir.

Tablo 3. Yeniçeri ocağının kaldırılması temasına ilişkin betimsel bulgular

\begin{tabular}{|c|c|c|}
\hline Kaynaklar & Bulgular & Bulgu Tespit Edilen Ders Kitapları \\
\hline $\begin{array}{l}\text { Ortaöğretim Tarih } \\
\text { Ders Kitapları }\end{array}$ & $\begin{array}{l}\text { Askeri (Ekonomik): } \\
\text { Yeniçeri Ocağı'nı isyana götüren etkenler; } \\
\text { - Devletin yaşadığı mali sıkıntılar. } \\
\text { - Alınan maaşları beğenmeme. } \\
\text { - Vergi muafiyeti ve iltizam sahibi olmak gibi ekonomik rant arayışı. } \\
\text { Idari (Ekonomik): } \\
\text { Şehirleşme ve Yönetim; } \\
\text { - İstanbul'un kentsel hizmetlerinin yürütülmesi sorunu }\end{array}$ & $\begin{array}{c}\text { 11. Sinıf (MEB yay./2., 4. ve } 6 . \\
\text { üniteler) }\end{array}$ \\
\hline $\begin{array}{l}\text { Haydar Kazgan'ın İlgili } \\
\text { Çalışmaları }\end{array}$ & $\begin{array}{l}\text { Ekonomik: } \\
\text { Yeniçeri Ocağı'nın devlet için oluşturduğu mali yük; } \\
\text { - Limanlardaki esnafla (Gedikler) Yeniçeri beraberliğinin yol açtığı yüksek } \\
\quad \text { fiyatlar. } \\
\text { - Ticari çıkarlarını olumsuz etkilemesi nedeniyle Batılı ülkelerin ocak } \\
\text { aleyhindeki baskıcı tutumu. } \\
\text { - Devletin vergi gelirlerini olumsuz etkilemesi. }\end{array}$ & \\
\hline
\end{tabular}

Tablodan lise tarih ders kitaplarında Yeniçeri Ocağının Kaldırılması konusunun doğrudan ekonomik bir bağlamda ele alınmamış olduğu anlaşılmaktadır. Konu daha çok ocağı isyana götüren ekonomik ve mali nedenler ve gerekçeler bağlamında ele alınmıştır. İlgili ders kitabında ocağın kaldırımasında daha çok askeri ve idari gerekçelerin ön planda tutulduğu anlaşılmaktadır. illgili ders kitabında bu konuya yönelik şöyle bir metin yer almaktadır (Yüksel, 2019b):

“...Yeniçeri İsyanları sadece başkentle sınırlı kalmamıştır. Vergi toplamak ve devlet işlerini yürütmek gibi görevlerle eyaletlerde çiftlikler kuran yeniçeriler, vergiden muaf olduklarından ticarete de başlamıştır. Zamanla eyaletlerdeki gelir kaynaklarına da el atan yeniçeriler, iltizam işleriyle uğraşmaya başlamıştır" (s.72).

Ders kitaplarında Yeniçeri Ocağı konusu bu şekilde ele alınmışken aynı konuyu Haydar Kazgan'ın çok daha farklı açılardan ele aldığı görülmüştür. Kazgan'a göre 19. yy.'da artan dış ticaret hacmi, limanda boşaltma ve yükleme faaliyetleri ve bu işlerle ilgili Lonca, Gedik gibi esnafla Yeniçeri beraberliğinin yol açtığı yüksek fiyatların Osmanlı Devleti’nden aldığı gümrük imtiyazlarından yararlanmak isteyen Batılı tüccarların ekonomik çıkarlarını etkilemekle birlikte bu limanlardan devletin aldığı vergi gelirlerinin de Yeniçeri ve esnaf beraberliği yüzünden ciddi kesintiye uğradığına dikkat çekmektedir. Kazgan aynı zamanda Batılı ülkelerin önemli bir ticaret hacmine sahip bir ithalat limanı olan İstanbul Limanı’nda esnafın yeniçerileri arkalarına alarak tekel oluşturmalarını kabul edemeyeceğine dikkat çekerek ocağın kaldırılmasındaki asıl etkenlerin bu gibi durumlar olduğunu vurgulamıştır. Kazgan ilgili çalışmasında bu konuya ilişkin şöyle bir metin yer almaktadır (Kazgan, 2005):

"Yeniçeriler de özellikle İstanbul'daki gedikler ile menfaat birliği içinde idiler; bunlarla açık veya kapalı ortaklıklar kurmuşlardı”. "...ilk olarak hamal gediklerini kullanarak, bunlara gemiden rıhtıma indirdikleri her yabancı mal için malın değeri kadar hammaliye ödenmesini talep etmişlerdir. Talepleri kabul edilmeyince yağmalara başvurmuşlar ve II. Mahmut'un yabancı elçilerin zoru ile Beyoğlu tepelerinde yabancı tüccarlar için kurdurduğu barakalara geceleri hücum ederek yakmaya koyulmuşlardır. Bütün bu olaylar yeniçeri desteği ile yapıldığı için 1826 yılında "Vakayı Hayriye" olayında yabancı elçilerin oynadığı rolü araştırmakta fayda vardır" (s.14).

Görüldüğü gibi Kazgan, Yeniçeri Ocağının Kaldırılmasındaki asıl etkenin ticaretin gelişmesini engelleyen tekelin kaldırılması ve vergi gelirlerinin artırılması olduğunu ifade etmektedir. Bu bağlamda özellikle yabancı elçilerin ocağın lağvedilmesinde oynadıkları rolün araştırılması gerektiğine de ayrıca dikkat çekmektedir. 


\section{Düyûn-ı Umûmiye Temasına i̇lişkin Bulgular}

Düyûn-ı Umûmiye konusuna lise tarih ders kitaplarında 11. ve 12. sınıfta yer verildiği ancak 11. sınıfta konun ekonomik boyutunun nispeten daha detaylı bir şekilde ele alındığı görülmüştür. Özellikle her iki ders kitabında da Düyûn-ı Umûmiye idaresinin (Genel Borçlar İdaresi) Osmanlı Devleti'nin mali bağımsızlı̆̆ını kaybetmesine yol açtığı fikrinin baskın şekilde işlendiği söylenebilir. Düyûn-ı Umûmiye temasına ilişkin araştırma bulgularına Tablo 4’te yer verilmiştir.

Tablo 4. Düyûn-ı Umûmiye temasına ilişkin betimsel bulgular

\begin{tabular}{|c|c|c|}
\hline Kaynaklar & Bulgular & Bulgu Tespit Edilen Ders Kitapları \\
\hline $\begin{array}{l}\text { Ortaöğretim Tarih Ders } \\
\text { Kitapları }\end{array}$ & $\begin{array}{l}\text { Okomik: } \\
\text { Ekonominin yabancı denetimi altına girmesi; } \\
\text { - Osmanlı Devleti mali bağımsızlığını kaybetmesi. } \\
\text { - Osmanlı gelirlerinin hazineye katkıının azalması. } \\
\text { - Yabancı sermaye sahipleri zenginliğini artırması. }\end{array}$ & $\begin{array}{l}\text { 11. Sınıf (MEB yay./4. ünite) } \\
\text { 12. Sınıf (MEB yay./1. ünite) }\end{array}$ \\
\hline $\begin{array}{l}\text { Haydar Kazgan'ın İlgili } \\
\text { Çalışmaları }\end{array}$ & $\begin{array}{l}\text { Ekomik: } \\
\text { - Osmanin yabancı denetimi altına girmesi; } \\
\text { Osmanlıt'nın dış borçları ödemede aciz kalması; } \\
\text { - Yabancı sermayeyi çekme mecburiyeti. } \\
\text { - Vergi kaynaklarının ıslahı ve artırılması. }\end{array}$ & \\
\hline
\end{tabular}

Tabloda belirtilen bulgular dikkate alındığında ders kitaplarında Düyun-ı Umumiye İdaresi'nin Osmanlı Devleti'nin mali olarak yaşadığı sorunların bir sonucu olarak ortaya çıktığı ve bu idarenin kurulması ile birlikte Osmanlı maliyesinin yabancı denetimi altına girdiği ve devletin ekonomik bağımsızıı̆ını kaybettiğine dikkat çekildiği anlaşılmaktadır. Ilgili ders kitaplarında bu konuya şöyle yer ayrılmıştır: "Düyûn-ı Umûmiye İaresi'nin kuruluşundan sonra Osmanlı ekonomisinin önemli bir kısmı kademeli olarak yabancıların denetimi altına girmiştir” (Yüksel, 2019b: 221). “...Bu idarenin kurulmasıyla Osmanlı maliyesi alacaklı devletlerin denetimi altına girdi. Bu olumsuz gelişmelerin ardından Osmanlı Devleti ekonomik bağımsızlığını kaybetti” (Çevik, Koç, ve Şerbetçi, 2019: 30).

Lise tarih ders kitaplarında Düyûn-ı Umûmiye konusunda ortaya konulan "Ekonominin yabancı denetimi altına girmesi" değerlendirmesinin Haydar Kazgan tarafından da yapıldığı söylenebilir. Ancak Kazgan’ın, konuyu çok farklı boyutları ile de -neden, sonuç, aktör ve dolaylı etki- ele aldığı ve analitik bir çerçevede işlediği söylenebilir. Kazgan ilgili çalışmasında bu konuya ilişkin şöyle bir metin yer almaktadır (Kazgan, 1985):

“...Muharrem Kararnamesi ile kurulan Düyunu Umumiye Idaresi gerek vergi kaynaklarının ıslahı ve hattâ bunların artııımasıyla ilgili gelir yaratıcı faaliyetleri teşvik ve düzenlemede, gerek vergi ve rüsum tahsili masraflarını asgariye indirmede, Osmanlı hükümetlerinin 1881 'e kadar görülen vergi ve malî politika ve uygulamalarına nazaran çok daha başarılı olmuştur." (s.704). “...Bu sayede Osmanlı İmparatorluğu hükümetleri daha on yıl geçmeden dünya borsalarında geçerli olan şartlarda yeni krediler almayı başarmışlardı" (s708).

Görüldüğü gibi ders kitaplarında Düyûn-ı Umûmiye konusunda yapılan vurgunun Haydar Kazgan'ın değerlendirmeleriyle örtüştüğü söylenebilir. Bununla beraber Kazgan'ın lise tarih ders kitaplarından farklı olarak Düyûn-ı Umûmiye idaresinin kurulmasının devlet için bir mecburiyete dönüştüğüne ve bu idarenin "vergi kaynaklarının ıslahı, gelir artırıcı tedbirler ve devletin dünya borsalarında geçerli bir itibar kazanmasına katkı sağlaması" gibi birtakım pozitif yönlerine de dikkat çektiği anlaşılmaktadır.

\section{Osmanlı Bankası Temasına iliş̧kin Bulgular}

Osmanlı Bankası konusuna lise tarih ders kitaplarında sadece 11. sınıfta yer yerilmiştir. Konunun ilgili ders kitabında ayrıntılı olarak işlenmediği ve ayrı bir başık olarak ele alınmadığı görülmüştür. Osmanlı Bankası temasına ilişkin araştırma bulgularına Tablo 5 'de yer verilmiştir.

Tablo 5. Osmanlı Bankası temasına ilişkin betimsel bulgular

\begin{tabular}{|c|c|c|}
\hline Kaynaklar & Bulgular & Bulgu Tespit Edilen Ders Kitaplar \\
\hline $\begin{array}{l}\text { Ortaöğretim Tarih Ders } \\
\text { Kitapları }\end{array}$ & $\begin{array}{l}\text { Ekonomik: } \\
\text { Yabancı Sermayenin Osmanlı'ya girişinde etkin rol oynama; } \\
\text { - Rahat/engelsiz sermaye akışı. } \\
\text { - Avrupa için yüksek faizli bir kazanç kapısı. } \\
\text { - Osmanlı için gittikçe ödenmesi zorlaşan borç yükü. } \\
\text { Siyasi (Ekonomik): } \\
\text { Bankaların siyasi baskı aracı olarak kullanılması; } \\
\text { - Avrupalı devlerin borç alması için Osmanlı'ya baskı yapması. }\end{array}$ & $\begin{array}{c}\text { 11. Sınıf (MEB yay./2. ve } 5 . \\
\text { üniteler) }\end{array}$ \\
\hline $\begin{array}{l}\text { Haydar Kazgan'ın Illgili } \\
\text { Çalışmaları }\end{array}$ & $\begin{array}{l}\text { Ekonomik: } \\
\text { Devletin finansal sömürü aracı olması; } \\
\text { - Devletin “Senyoraj Hakkı”nı engellemesi. } \\
\text { - Devletin borç yükünü artırması. } \\
\text { - Avrupa finans kapitalinin Osmanlı ithalatını finanse etmesi. }\end{array}$ & \\
\hline
\end{tabular}


Tablodan anlaşıldığı üzere ders kitaplarında Osmanlı Bankası'nın ekonomik bağlamda ele alınırken diğer benzeri bankalarla birlikte anıldığı; konunun yalnızca Osmanlı borçları ile bağlantısına dikkat çekilerek "Yabancı sermayenin (Avrupalı devletler/zenginler) Osmanlıya borç verme aracı" olarak görüldüğü ve bu bağlamda da "siyasi baskı aracı"na dönüştüğü vurgusunun yapıldığı anlaşılmaktadır. Bu durum ilgili ders kitabında şöyle yansıtılmıştır (Yüksel, 2019b):

“XVIII. yüzyılın ikinci yarısından itibaren Avrupa, Osmanlı Devleti’ne sadece mal satmakla yetinmeyip sermaye yatırımı da yapmaya başlamıştır. Büyük bankalar tarafından tahviller aracılığı ile devletlere borç vermek kazançlı bir iş hâline gelmiştir. Böylece Avrupa devletlerinin borç alan ülkeyi mali kontrol altına alması da kolaylaşmıştır. Bu yüzden İngiltere ve Fransa kendilerinden borç alması için Osmanlı’ya baskı yapmıştır” (s.202).

Aynı konuyu Haydar Kazgan’ın, ilgili çalışmalarında çok farklı boyutları ile -neden, sonuç, aktör ve dolaylı etki- değerlendirdiği söylenebilir. Kazgan özellikle bu bankanın kuruluş gerekçelerine vurgu yaparak Avrupa finans kapitalinin Osmanlı Bankası aracılığıyla Osmanlı ithalatını finanse etmek suretiyle aslında kendi sanayi ürünleri için çok elverişli talepler yarattığını savunmuştur. Kazgan'ın ilgili çalışmasında bu konuya ilişkin şöyle bir metin yer almaktadır: “Avrupa ülkeleri - özellikle İngiltere ve Fransa - gerek dış ticaret ve gerekse Osmanlı hükümetine verilecek dış borçlar için kendileri tarafından güdümlü bankaların kurulmasının faydalı olacağını düşünmektedirler" (Kazgan, 1995: 181).

Osmanlı Bankası konusunda gerek lise ders kitaplarında gerekse birçok çalışmada değinilmeyen ama Haydar Kazgan tarafından vurgulanan en önemli değerlendirmenin hiç şüphesiz "Senyoraj Hakkı” meselesi olduğu söylenebilir. Kazgan Osmanlı Devleti'nin finansal olarak ciddi sorunlar yaşadığı dönemde Osmanlı Bankası'nın kurulması ve adeta bir merkez bankası gibi yetkilerle donatılması yüzünden devletin başlangıçta devreye sokamadığı kağıt para basımından kaynaklı emisyon kazançlarından (senyoraj hakkı/tuğra hakkı), bankanın kurulmasını izleyen yıllarda dışarıdan müsaade edilmemesi yoluyla tamamen mahrum bırakıldığına dikkat çekmektedir. Kazgan'ın ilgili çalışmasında bu konuya ilişkin şöyle bir metin yer almaktadır (Ulçenko ve Kazgan, 2003):

“Kırım Savaşı ayrıca Osmanlı gümüş para sistemine de büyük etki yapmıştır. Rusya'dan gümüş ithali bir müddet için de olsa kesilince Osmanlı Devleti, gümüş paraların ayarını düşürmek zorunda kalmıştır. Zaten kâğıt kaimelerle alt üst olan para sistemi, bu defa hem kâğıt hem madeni para olarak İngiliz ve Fransız paralarının içeride tedavüle girmesiyle Osmanlı Devleti'nin senyoraj hakkının zedelenmesinin etkisini yaşamıştır. Bunun sonucu olarak İngiliz ve Fransızların eline geçen kaimeleri ve kâğıt paraları ortadan kaldırmak için bu iki ülkeden devamlı dış borç almak zorunluluğu ortaya çıkmıştır" (s.39).

Haydar Kazgan, Osmanlı Bankası'nın olumlu yönlerinde de dikkat çekmiştir. Kazgan, iç borçlanmada aktif rol alan bankanın dış borçlanmada da önemli bir garantör olduğuna ve Osmanlı Devleti'nin finansal açıdan Avrupa'yla entegrasyon sürecini hızlandırdığına vurgu yapmıştır.

\section{7-78 Osmanlı-Rus Savaşı Temasına iliş̧kin Bulgular}

Lise tarih ders kitaplarında 1877-78 Osmanlı-Rus Savaşı́nın ekonomik boyutuyla çok fazla işlenmediği görülmüştür. Oysaki Haydar Kazgan'ın bu konuyu birçok ekonomik faktör bağlamında ele aldığı söylenebilir. 1877-78 Osmanlı-Rus Savaşı temasına ilişkin araştırma bulgularına Tablo 6'da yer verilmiştir.

Tablo 6. 1877-78 Osmanlı-Rus Savaşı temasına ilişkin betimsel bulgular

\begin{tabular}{|c|c|c|}
\hline Kaynaklar & Bulgular & Bulgu Tespit Edilen Ders Kitapları \\
\hline $\begin{array}{l}\text { Ortaöğretim Tarih } \\
\text { Ders Kitapları }\end{array}$ & $\begin{array}{l}\text { nomik: } \\
\text { Balkan göçmenlerin iskân sorunu; } \\
\text { - Göçmenlere yönelik muafiyeler (belirtilmemiş) } \\
\text { - Pek çok ekonomik ve sosyal sıkıntı (belirtilmemiş) } \\
\text { - Hazinede oluşana mali açığı kapatmak için dış borç alma yönelimi. }\end{array}$ & 11. Sınıf (MEB yay./ 4. ünite) \\
\hline $\begin{array}{l}\text { Haydar Kazgan'ın } \\
\text { İlgili Çalışmaları }\end{array}$ & $\begin{array}{l}\text { nomik: } \\
\text { Devletin finansal/mali sorunlar yaşaması; } \\
\text { - Devletin iç ve dış borç yükünü artıran savaş harcamaları sorunu. } \\
\text { - Savaşın } 1875 \text { 'te Moratoryum ilanı ile ilişkisi. }\end{array}$ & \\
\hline
\end{tabular}

Tablodan da görüldüğü gibi ders kitaplarında 1877-78 Osmanlı-Rus Savaşı’nın ekonomik boyutu sadece savaşın etkisiyle balkan bölgesinden Anadolu'ya doğru oluşan göç dalgasının devlete getirdiği mali yük ve bu yükün finanse edilmesi bağlamında oldukça dar ve belirsiz değerlendirmelere dayandırılarak işlendiği söylenebilir. Illgili ders kitabında bu konuya yönelik şöyle tespitler yer almıştır (Yüksel, 2019b):

“93 Harbi sonrası daralan Osmanlı topraklarına göç etmek zorunda kalan Türk ve Müslümanların büyük bir kısmı İstanbul'a ve Anadolu'ya, diğer bir bölümü de Batı Trakya’ya yerleşmiştir. Toplandıkları merkezlerde öncelikle bu göçmenlerin geçici iskânlarına çalışılmış ancak daha sonra sürekli iskân için ciddi çalışmalar yapılmıştır" (s.215). “...Devletin normal masrafları, iskân masrafları ile birleşince artmış, hazine de bu açığı kapamak için dış borçlanma yoluna gitmiştir" (s.216).

Lise tarih ders kitaplarına nispeten 1877-78 Osmanlı-Rus Savaşı’nın, Kazgan tarafından çok farklı yönleriyle irdelendiği görülmüştür. Kazgan özellikle de savaşın devlet için oluşturduğu ekonomik yükün dış borçlanma yükünü artırması yönüne dikkat 
çemiştir. Kazgan aynı zamanda 1875'teki “Moratoryum İlanı”na da dikkat çekerek Rusların Osmanlı Devleti’nin içine düştüğü ekonomik çıkmazdan yararlanma saikiyle savaş ilanını, Osmanlı Devleti'nin “moratoryum” ilan ettiği bir zamana tesadüf ettirdiğine vurgu yapmıştır. Kazgan'ın ilgili çalışmasında bu konuya şöyle değinilmiştir (Kazgan, 1995):

“...Ruslar bu savaşa daha evvelden hazırlandıkları için, dış borçlarının büyük bir kısmını ordunun donatılmasına ve yeniden organizasyonuna sarf etmişlerdi. Oysa Osmanlı İmparatorluğu'nun aldığı borçlarda orduya düşen pay çok düşük kalmıştı. Bu sebeple Rusların Plevne'yi zaptından sonra durumunun kritik bir hale gelmesi, yeni bir dış borç için, Batılılara müracaatı gerektirmişti" (s.134).

Görüldüğü gibi Kazgan bu savaşı, Osmanlı’nın borç yükünü artıran ve dış borca sürükleyen en önemli unsur olarak savaş harcamaları bağlamında ele alınması gerektiğine dikkat çekmektedir. Aynı döneme Osmanlı'nın 1875'te Moratoryum ilanı (devletin iflası) ile savaşın ilişkisine dikkat çeken Kazgan, devletin bu iflas yüzünden Avrupa finans kapitali karşısında itibar kaybettiği ve borç almakta zorlandığına dikkat çekmiştir.

\section{Galata Bankerleri Temasına ilişkin Bulgular}

Galata Bankerleri konusuna lise tarih ders kitaplarında yer ayrılmış olması, araştırmanın dikkat çeken bulgularından biridir. Tarih 11. sınıf ders kitaplarında Osmanlı́nın iç ve dış borçları, bütçe açıklarının kapatılması ve Düyûn-ı Umûmiye konusu işlenirken Galata Bankerleri konusuna da değinildiği görülmüştür. Galata Bankerleri temasına ilişkin araştırma bulgularına Tablo 7'de yer verilmiştir.

Tablo 7. Galata Bankerleri temasına ilişkin betimsel bulgular

\begin{tabular}{|c|c|c|}
\hline Kaynaklar & Bulgular & Bulgu Tespit Edilen Ders Kitapları \\
\hline $\begin{array}{l}\text { Ortaöğretim Tarih } \\
\text { Ders Kitapları }\end{array}$ & $\begin{array}{l}\text { nomik: } \\
\text { Bütçe açıklarına çözüm arayışı; } \\
\text { - Bankerlerden yüksek faizli kredilerin alınması. } \\
\text { - Avrupalı devletlere borçlanmanın alternatifi olarak görülmesi. } \\
\text { Osmanlı ekonomisinde geniş bir hareket alanına sahip olmaları; } \\
\text { - Hükûmetin para ve maliye politikalarını belirlemeleri }\end{array}$ & 11. Sınıf (MEB yay./5. ünite) \\
\hline $\begin{array}{l}\text { Haydar Kazgan'ın } \\
\text { İlgili Çalışmaları }\end{array}$ & $\begin{array}{l}\text { nomik: } \\
\text { Devletin savaş giderlerini finanse etme arayışı (iç borç); } \\
\text { - Bankerlerin kişisel çıkar hesapları } \\
\text { - Bankerlerin yüksek faizli kazançlarına razı olma } \\
\text { Osmanlının açık pazar haline gelmesi (sömürü düzeni); } \\
\text { - Devletin Batının devamlı pazarı haline getirilmesindeki payları } \\
\text { - Borsa oyunları (spekülasyon) ile devleti/halkı zarara uğratma. } \\
\text { - Devletin hemen her ekonomik ve ticari faaliyetini kontrol etme }\end{array}$ & \\
\hline
\end{tabular}

Lise tarih ders kitaplarında Galata Bankerleri konusuna yer verilmiş olsa da diğer konularda olduğu gibi bu konuya da ekonomik bağlamda oldukça yüzeysel bir şekilde değinildiği söylenebilir. Illgili ders kitabında bu konuya ilişkin şöyle bir metin yer almaktadır: "XVII. yüzyılın ortalarına kadar yaşanan bütçe açıkları, Galata bankerleri olarak bilinen sermaye sahiplerinden alınan kredilerle kapatılmıştır" (Yüksel, 2019b: 202). Görüldüğü gibi devletin bütçe açıklarının kapatılması amacıyla Galata Bankerlerinden kredi alındığına dikkat çekilmiştir. Bir başka metinde ise Galata Bankerlerinin hükûmetin para ve maliye politikaları üzerindeki etkisine dikkat çekildiği anlaşılmaktadır. "Galata bankerleri olarak bilinen gayrimüslim sermaye sahipleri Osmanlı ekonomisinin her alanına hâkim olmaya çalışmıştır. Bunun sonucunda gayrimüslimler, hükûmetin para ve maliye politikalarını yürütür konuma gelmiştir." (Yüksel, 2019b: 205).

Galata Bankerleri konusunda ders kitaplarında yapılan değerlendirmenin Haydar Kazgan'ın değerlendirmeleriyle de örtüştüğü söylenebilir. Ancak Kazgan'ın bu konuyu bütün yönleriyle el aldığı ve Osmanlı'nın son yüz yılık döneminin anlaşılmasında Galata Bankerleri konusunun önemli bir yeri olduğuna dikkat çektiği anlaşılmaktadır. Kazgan Galata Bankerlerinin Osmanlı Devleti’nde önemli bir yapı haline gelmesinin ilk örneğinin 1877-1878 Osmanlı Rus Savaşı sürecinde devletin borç bulma konusunda yaşadığı sorununu Galata Bankerleri ile çözme girişimiyle başladığına dikkat çekmektedir. İlgili çalışmasında Kazgan, bu dönemde devletin savaş masraflarını finanse etme konusunda düştüğü acziyete dikkat çekerek şöyle bir durum tespiti yapmaktadır (Kazgan, 2005):

“...Işste bu sıkıntılı ortam içinde Galata Bankerleri ehveni şer olarak ortaya çıkıyorlardı. Galata Bankerleri gerçekte İstanbul'u veya Galata'yı Ruslara teslim etmemek için ellerinden geleni yapmaya mecburdular. İşleri güçleri Osmanlı Devleti'nin, hatta onun bozuk mali düzeninin devamına bağlı idi. Ne devletin yok olmasını ne de mali işlerin düzelmesini isterlerdi." (s.135).

Burada da ifade edildiği gibi her ne kadar devlet için kurtarıcı bir rol üstlenmiş gibi görünseler de esasında Galata Bankerlerinin tek önemsedikleri şeyin kendi menfaatleri olduğu anlaşılmaktadır. Kazgan, Galata Bankerlerinin Osmanlının Sanayi Devrimi sonrası açık pazar haline gelmesindeki rolüne de dikkat çekmektedir. Kazgan bu konuya ilgili çalışmasında şöyle değinmektedir: “Galata Bankerleri'nin Türk ekonomisindeki asıl önemli rolü Batı'daki sanayi devrimi ile ağırlık kazanmakta ve Osmanlı İmparatorluğu' nun Batı için devamlı pazar haline getirilmesinde bu bankerlerin rolü konuya bütün açıklığını getirmektedir." (Kazgan, 2005: 13). Bir başka yerde ise Kazgan'ın Galata Bankerlerinin spekülatif oluşturma ve bu parasal spekülatif ortamından yararlanma girişimlerine dikkat çektiği görülmektedir. Bu duruma ilgili çalışmasında şöyle dikkat çekmektedir (Kazgan, 2005): 
“ístanbul Bankası'nın kapanması ile devletin hazine açıklarını kapatmak için devamlı olarak piyasaya sürmeye başladığı kaimeler vardı. Bu kaimeler banka desteğinden yoksun kalınca müthiş bir spekülasyona sebep oldular ve Galata Bankerleri, bu kaimelerin kurunu her an suni bir şekilde değiştirmek gücüne erişerek, devlet ve halkın büyük zararları pahasına büyük kazançlar elde ettiler (s.20).

Kazgan'ın Galata Bankerlerinin Osmanlı Devletindeki etkin rolüne ve devletin hemen her ekonomik ve ticari faaliyetinin arkasında izinin olduğuna dikkat çekmesi yine önemli bulunan bulgulardan biridir. illgili çalışmasında bu duruma şöyle dikkat çekmektedir (Kazgan, 2005):

“1860'lardan itibaren Galata'daki Komisyon Han'ı ve Havyar Han'ında finans imparatorluklarını kurmuş olan Galata Bankerleri, Saray'dan başlayıp vezir, vükela, memur ve subaydan, İmparatorluğun en uzak köşesindeki tahıl ya da meyva üreticisine, oduncusuna, kömürcüsüne ve her türlü esnafına kadar uzanan bir ağ kurmuş bulunuyorlardı. Adeta İmparatorluğun milli geliri ve dışardan aldığı borçların hatırı sayılır bir yüzdesi borsa oyunları, tefecilik, murabahacılık işlemleri ile bu bankerlerin eline geçer hale gelmişti" (s.62).

\section{Gedikler Temasına iliş̧kin Bulgular}

Araştırma kapsamından yapılan analizlerde lise tarih ders kitaplarında Gedikler konusuna sadece 10. sınıflarda yer verildiği bulgusuna ulaşılmıştır. İlgili ders kitabında gedikleri konusuna çok az değinildiği ve sadece kuruluş amacına yönelik kısa bir bilgi vermekle yetinildiği görülmüştür. Gedikler temasına ilişkin araştırma bulgularına Tablo 8'de yer verilmiştir.

Tablo 8. Gedikler temasına ilişkin betimsel bulgular

\begin{tabular}{|c|c|c|}
\hline Kaynaklar & Bulgular & Bulgu Tespit Edilen Ders Kitapları \\
\hline \multicolumn{3}{|c|}{ Ekonomik: } \\
\hline $\begin{array}{l}\text { Ortaöğretim Tarih } \\
\text { Ders Kitapları }\end{array}$ & $\begin{array}{l}\text { Gedik sisteminin kuruluş amacı ve özelliği; } \\
\text { - Esnafın korunması (haksız rekabetin önlenmesi) } \\
\text { - Esnaf tekelciliği. }\end{array}$ & 10. Sınıf (ILKE yay./7. ünite) \\
\hline $\begin{array}{l}\text { Haydar Kazgan’ın } \\
\text { İlgili Çalışmaları }\end{array}$ & $\begin{array}{l}\text { Osmamik: } \\
\text { - Yeniçerilerle işbirliği ve bozgunculuk faaliyetleri. } \\
\text { - Esnaflar ve mülk sahipleri üzerinde baskı unsuru. } \\
\text { - Şehrin dokusuna zarar verme } \\
\text { Osmanlı maliyesini zarara uğratma; } \\
\text { - Usulsüz vergi ve haraç toplama. } \\
\text { - Liman gelirlerini tekelinde bulundurma. }\end{array}$ & \\
\hline
\end{tabular}

Tabloda görüldüğü gibi 10. sınıf ders kitabında Gediklerin Osmanlı ekonomisi içerisindeki yerine, olumlu ya da olumsuz yönlerine ilişkin bir içeriğin paylaşılmadığı söylenebilir. İlgili ders kitabında bu konuya yönelik şöyle bir metne yer verilmiştir (Yılmaz, 2019):

"Ticari ve endüstriyel herhangi bir mesleğe devam etme imtiyazına "gedik" denirdi." "...Loncalar, özellikle gediklerin haksızlık olmadan dağıımına büyük bir özen gösterirdi. Gediklerin en önemlisi, bir çeşit imtiyaz ve tekel usulü olan esnaf gedikleriydi. Esnaf gediklerinin işlediklerini başkası işleyemez, sattıklarını başkası satamazdı. Bu kurala uymayanlar cezalandırılırdı" (s.176).

Bu bağlamda ders kitaplarında gedikler konusunun lonca anlayışının sahadaki örneklerinden biri olduğuna yönelik sınırlı bir bilginin yer aldığı söylenebilir. Diğer yandan Haydar Kazgan'ın Gedikler konusunu farklı boyutlarıyla ele aldığı anlaşılmaktadır. Kazgan'ın Gediklerin son dönem Osmanlı ekonomik toplumu içerisinde gittikçe bozulan ve hem toplumsal yapıya hem de kurumsal yapıya zarar veren bir kuruma dönüştüğüne özellikle dikkat çektiği görülmektedir. İlgili çalışmaları incelendiğinde Gedikler ve Yeniçeri Ocağı arasındaki ilişkiye sıklıkla değindiği ve Gediklerin Yeniçeri Ocağının bozulması ile paralel bir bozulma seyrine girdiğine yönelik tespitlerde bulunduğu dikkati çekmektedir. Gedikler ile Lonca teşkilatı arasında ilişki konusunda ders kitaplarına paralel bir açıklamanın Kazgan tarafından da getirildiği söylenebilir. Kazgan ilgili çalışmasında bu durumu şöyle yansıtmaktadır: “...Imparatorluğun iç pazarlama düzeninde o devirde bir nevi esnaf loncaları olan "Gedikler" hala hâkim durumda idiler. Bu gedikler İstanbul ve civarında ve İmparatorluğun her tarafına yayıımış üretici loncaları ile iş birliği içinde bulunuyorlardı" (Kazgan, 2005: 14).

Kazgan'ın Gedikler konusunda en önemli vurgusunun ise Gediklerin Yeniçeri nüfusunu kullanarak usulsüz uygulamalara başvurmaları konusu olduğu söylenebilir. Bu usulsüzlüklere ilişkin tespitleri oldukça önemlidir (Kazgan, 2005):

"Yeniçeriler İstanbul'daki Gedik esnafı ile bir olup ithal mallarına ve Galata'da mallarını pazarlayan tüccara karşı gaddarca hareket etmeye başlayınca durum daha da kötüleşmiş ve Galata bir ara en önemli gelir kaynağı olan ithal malları ve deniz trafiğine bağlı gelirleri tamamen yitirmiştir" (s.14).

Görüldüğü gibi Gediklerin Yeniçeri nüfusunu kullanarak o dönemde devletin önemli gelir kalemlerinden biri olan ithalata ve deniz ticaretine ilişkin vergi gelirlerine usulsüzce el koyduğu anlaşılmaktadır. Diğer taraftan özellikle Yeniçeri Ocağının kaldırılması ile birlikte Gediklerin hâkimiyet alanın daraldığına da dikkat çekmiştir. Kazgan bu durumu şöyle izah etmektedir: "Yeniçerilerin ortadan kaldırılması ile Gediklerin imtiyazlarını tahdit eden hükümler yürürlüğe konmuş ve zamanla daha da sertleştirilerek 
bunların ticaret ve üretim hayatımızdaki rollerinin 19. asrın sonuna doğru tamamen ortadan kalkması sağlanmıştır." (Kazgan, 2005: 14-15).

\section{Osmanlı İç ve Dış Borçları Temasına İlişkin Bulgular}

Araştırmanın son teması olan Osmanlı İç ve Dış Borçları konusunun lise tarih ders kitaplarında oldukça detaylı bir şekilde ele alındığı söylenebilir. İncelemeler sonucunda Osmanlı iç ve Dış Borçları konusuna 11. ve 12. sınıf ders kitaplarında yer verildiği bulgusuna ulaşılmıştır. Özellikle 11. sınıf tarih ders kitabında bu konunun iki ayrı ünitede ekonomik ve siyasi boyutları başta olmak üzere birçok açıdan irdelenmiş olduğu söylenebilir. Bu bağlamda Osmanlı İç ve Dış Borçları temasına ilişkin araştırma bulgularına Tablo 9'da yer verilmiştir.

Tablo 9. Osmanlı iç ve dış borçları temasına ilişkin betimsel bulgular

\begin{tabular}{|c|c|c|}
\hline Kaynaklar & Bulgular & Bulgu Tespit Edilen Ders Kitapları \\
\hline $\begin{array}{l}\text { Ortaöğretim Tarih } \\
\text { Ders Kitapları }\end{array}$ & $\begin{array}{l}\text { OIIlk dış̧ borç ( } 24 \text { Ağustos 1854/Ingiltere ve Fransa); } \\
\text { - Savaşın mali yükünün altından kalkamama gerekçesi (Örn. Kırım Savaşı) } \\
\text { Bütçe açıkları; } \\
\text { - Artan savaş maliyetleri, } \\
\text { - Vergi gelirlerinin azalması, } \\
\text { - Değişen dış ticaret yapısı. } \\
\text { Sanayileşme yarışında geri kalma; } \\
\text { - Ağır borç yükü sanayiye gereken kaynağın ayrılmasına engel oldu. } \\
\text { Plansız ve kontrolsüz borçlanma; } \\
\text { - Gelir kaynaklarını teminat gösterme, } \\
\text { - Plansız ve işlevsiz kamu harcamalarına harcama, } \\
\text { - Saray, köşk vb. yapımlara harcama, } \\
\text { - Borcu borçla ödeme, } \\
\text { - Yüksek faizle borçlanma. }\end{array}$ & $\begin{array}{l}\text { 11. Sınıf (MEB yay./3. ve } 5 . \\
\text { üniteler) } \\
\text { 12. Sınıf (MEB yay./1. ünite) }\end{array}$ \\
\hline $\begin{array}{l}\text { Haydar Kazgan'ın } \\
\text { İlgili Çalışmaları }\end{array}$ & $\begin{array}{l}\text { ronomik: } \\
\text { Dış borçlanma mecburiyeti; } \\
\text { - Dış kaynak ihtiyacı bu yolla karşılama. } \\
\text { - Ordunun ve ekonominin modernleştirilmesi. } \\
\text { Avrupa finans kapitalinin Osmanlıyı çökertmesi; } \\
\text { - “Kumarhane kapitalizmi” benzetmesi } \\
\text { - Osmanlının finansal ve ticari oyunlarla sömürülmesi }\end{array}$ & \\
\hline
\end{tabular}

Ders kitaplarından elde edilen bulgular incelendiğinde, Osmanlı İç ve Dış Borçları konusunun özellikle de Kırım Savaşı örneğinden yola çıkılarak savaş maliyetlerinden doğan ihtiyaca binaen gündeme geldiğine vurgu yapıldığı görülmektedir. Devlet o zamana kadar dış borçlanma yapmama politikası yürütürken bir taraftan da iç borçlanma yoluyla var olan açı̆̆ı kapama yoluna gitmiştir. Ancak Kırım Savaşı ile birlikte dış borçlanma kapısını aralayan devletin daha sonraki süreçte kapılarını ardına kadar açtığı ve plansız ve kontrolsüz borçlanma politikaları nedeniyle de dış borçlarını ödeyemez duruma düştüğüne dikkat çekilmiştir. illgili ders kitabına bu duruma ilişkin bazı metinler paylaşılmıştır (Yüksel, 2019b):

“XVII. yüzyılın ortalarına kadar yaşanan bütçe açıkları, Galata bankerleri olarak bilinen sermaye sahiplerinden alınan kredilerle kapatılmıştır. Ancak Osmanlı'daki idari yapı ve ordunun modernleştirilme çabaları, devlet harcamalarının daha da artmasına neden olmuştur." (s.202). "Osmanlı Devleti, XIX. yüzyıl boyunca daha fazla ve daha yüksek faizle borçlanmaya devam etmiştir. Alınan dış borçların sadece \%7,8'i Rumeli demiryolu yatırımına ayrılmıştır. Geriye kalan büyük kısım ise plansız ve kontrolsüz kamu harcamalarına, borç taksitlerinin ödenmesine, sarayların yapımına, orduya ve devlet memurlarının maaşlarının ödenmesine harcanmıştır. Böylece ödenemeyen dış borçlar yeni borçlanmaları da beraberinde getirmiştir." (s.202).

Görüldüğü gibi ilk zamanlar çoğunluğu yabancı uyruklu sarraflardan oluşan içerdeki Galata Bankerlerinden yüksek faiz/komisyon karşıı̆̆ı borç para alan devletin daha sonraki süreçte dış borca yönelmek durumunda kaldığına dikkat çekilmektedir. Ders kitaplarında bu konuda dikkat çekilen diğer hususun ise devletin dış borç karşılığı önemli gelir kaynaklarını teminat göstermesi sonrası bu gelir kalemlerinin batılı sermayenin denetimi altına girmesinin, devleti iflasa ve çıkmaza sürükleyen önemli sorunlardan biri olduğudur. Lise tarih ders kitaplarında bu konuda ulaşılan bir başka önemli bulgu ise yüksek faizler ve alınan borçların gereksiz yerlerde harcanması yüzünden iyice ağır borç yükü altına giren devletin sanayiye gereken kaynağı ayıramaması nedeniyle sanayileşme yarışında Avrupa'nın gerisinde kalmış olmasına yapılan vurgudur. İlgili ders kitabında bu konuya da şöyle yer verilmiştir (Yüksel, 2019b):

“...Sultan Abdülmecid, düzenli bir bütçe çıkarmak ve uygulamak için bir komisyon oluşturulmasını emretmiştir. Ancak kamu harcamalarında tasarrufa uyulmadığı için bu komisyon olumlu bir sonuç elde edememiştir." “...Ekonomik hayatı canlandıracak yatırımlara kaynak ayrılamadığı için borçlar giderek ödenemez olmuş ve en sonunda da Osmanlı maliyesi iflas etmiştir." (s.203). 
Araştırma bulguları ders kitaplarında Osmanlı İç ve Dış Borçları konusunda yapılan değerlendirme ve tespitlerin Haydar Kazgan'ın değerlendirme ve tespitleriyle büyük oranda örtüştüğünü ortaya koymuştur. Kazgan'ın da Osmanlı Devleti'nin iç ve dış borçlanmasında etkili olan faktörlerden "Galata Bankerleri, Kırım Savaşı, 1877-78 Osmanlı Rus Savaşı, Kapitülasyonlar, vergi gelirleri, bütçe açıkları, gereksiz tüketim harcamaları vs.” gibi birçok faktörü değerlendirdiği anlaşılmaktadır. Ancak Kazgan’ın ders kitaplarından farklı olarak Osmanlı Devleti’nin dış borçlanmasını eleştirmenin bir yönüyle yanlışlığına dikkat çektiği görülmektedir. Kazgan'a göre devletin dış kaynak ihtiyacı esas itibariyle bu yolla karşılanıyordu ve dış borçlanma ordunun ve ekonominin modernleşmesi için hayati bir öneme sahipti. Bununla birlikte Kazgan, Avrupalı devletlerin Osmanlıyı dış borçlanma silahıyla vurduğuna vurgu yapması manidardır. Haydar Kazgan'ın "Kumarhane Kapitalizmi” olarak ifade ettiği paradan para kazanan iç ve dış sermayenin (Avrupa Finans Kapitali) oyunlarına sıklıkla vurgu yaptığı dikkati çekmektedir. Kazgan'a göre "Düveli Muazzama», savaşlar ve silah satışları yoluyla Osmanlı’yı güçsüzleştirirken, alınan imtiyazlar, kapitülasyonlar, ağır borçlar ve borç faizleri üzerindeki oyunlarla da başka türlü bir sömürüyü buna koşut bir biçimde yürütmekteydi (Kazgan, 2005).

\section{SONUÇ VE TARTIŞMA}

Araştırmada elde edile bulgular, karşılaştırmalı olarak incelenen 8 olay ve kuruma ilişkin sunulan yorum, tespit, değerlendirme ve ilişkilendirmeler bağlamında lise tarih ders kitapları ile Haydar Kazgan'ın ekonomi ve finans tarihi çalışmaları arasında önemli farklılıkların olduğunu ortaya koymaktadır. Lise tarih ders kitaplarında tarihi olay ve kurumların öğretiminde ekonomi disiplinin temel kavramlarından yeterince yararlanılmadı̆̆ı, dolayısıyla ders kitaplarının okuyucuya tarih öğretimi amacıyla ekonomi eksenli bir bakış açısı sunma konusunda daha zengin bir içeriğe sahip olmasının gerektiği söylenebilir.

Lise tarih ders kitaplarında incelenen 8 temadan sadece Kapitülasyonlar, Osmanlı İç ve Dış Borçları ve Düyûn-ı Umumiye konularının ekonomik sebep ve sonuçları boyutuyla nispeten yeterli ölçüde yansıtılmış olduğu anlaşılmaktadır. Ancak Yeniçeri Ocağının Kaldırılması, Galata Bankerleri, Osmanlı Bankası, Gedikler ve 1877-78 Osmanlı-Rus Savaşı konularının ise ya yeterince işlenmediği ya da ekonomik bir perspektiften bağımsız olarak sadece kişiler, olaylar ve kronoloji bağlamında sınırlı bir şekilde yansıtılmış olduğu sonucuna ulaşılmıştır. Diğer yandan Haydar Kazgan'ın ilgili çalışmalarında, incelen 8 temanın tamamının ekonomik ve finansal boyutlarıyla "neden, sonuç, aktör ve dolaylı etki" bağlamında detaylıca ve sistematik bir şekilde ele alındığı sonucuna ulaşıımıştır. Bu durum ders kitaplarında yoğun bir şekilde tartışılan bu tarihi olay ve kurumların, Haydar Kazgan'ın aynı konuları ele alırken takip ettiği ekonomik ve finansal bağlamın oldukça uzağında ve sınırlı bir ekonomik ve finansal neden sonuç ilişkisi kurgusu çerçevesinde ele alındığını ortaya koymaktadır. Örneğin ders kitaplarında yoğun şekilde ele alınmış olan Kapitülasyonlar konusunun okuyucuya Osmanlı́nın ekonomik ve finansal açıdan çöküşe sürüklenmesine yönelik bir bağlam kurma fırsatı sunmaktan uzak kaldığı görülmüştür. Ancak Haydar Kazgan'ın aynı konuyu ele alış biçiminin ders kitaplarındaki bu kısır anlayıştan oldukça farklı olduğu anlaşılmaktadır. Kazgan’ın Kapitülasyonların Batılı devletlerce (Düvel-i Muazzama) Osmanlıyı ekonomik olarak zayıflatmaya yönelik bir “Finansal Sömürü Aracı”na dönüştürdüğüne ilişkin tespit ve değerlendirmelerinin, ders kitaplarındaki birçok vurguyu özetler nitelikte olduğu söylenebilir. Bir başka örnek ise Osmanlı Bankası'dır. Osmanlı Bankası konusunda lise tarih ders kitaplarında oldukça yetersiz bir içeriğin sunulduğu görülmüştür. Diğer taraftan aynı konuyu Kazgan'ın birçok açıdan, olumlu ve olumsuz yönleriyle ele aldığı söylenebilir. Kazgan'ın Osmanlı Bankası'nın devletin senyoraj hakkını kullanmasını engellemesiyle giderek nasıl bir borç batağına girildiğini, geçmişin nasıl pazar ve finans oyunlarıyla yoğrulduğunu (Kazgan, 2011: 12) ortaya koyarak okuyucuya aynı konuya ekonomik ve finansal bir perspektiften bakma fırsatı sunabildiği tespitlerinin lise tarih ders kitaplarında hiçbir şekilde yansıtılmadı̆̆ı sonucuna ulaşılmıştır. Kazgan'ın özellikle Galata Bankerleri ve Gedikler konusunda ortaya koyduğu tespitlerin lise tarih ders kitaplarında oldukça sınırlı bir şekilde yansıtılmış olması araştırmada dikkat çeken bir diğer husus olmuştur. Her ne kadar lise tarih ders kitaplarında Galata Bankerleri'ne yönelik bir içeriğe yer verilmiş olsa da (Yüksel, 2019b), dağılma sürecinin daha iyi anlaşılmasında Osmanlı Devleti'nin Batının devamlı pazarı haline getirilmesinde ve yoğun şekilde yürüttükleri borsa oyunları (spekülasyon) ile hem devleti hem de halkı zarara uğratma konusunda finansal açıdan Galata Bankerlerinin üzerinde daha detaylıca durulması gerektiği söylenebilir.

Tarih öğretimi konusunda ders kitaplarının yeri yadsınamayacak derecede önemlidir. Araştırma sonuçları, ülkemizdeki lise tarih ders kitaplarının diğer sosyal bilim disiplinlerinin kavram, yöntem ve yaklaşımlarından uzak kaldığı ve bütüncül bir tarih öğretimi anlayışına hizmet etmek konusunda özellikle çalışmanın odağında yer alan ekonomi disiplini bağlamında irdelendiğinde yetersiz kaldığını ortaya koymaktadır. Tarih'in ekonomik bir bakış açısı eksikliğiyle yorumlanmaya çalışılması yanlış anlaşılmaları ve kavram yanılgılarını artırabilir. Tarih önemli bir disiplin olmasının yanında tarih öğretimi konusunda sorunlar ve şikayetler de bir o kadar fazladır. Çoğu araştırmada öğrencilerin tarih derslerini gerçek/belirgin bir amacı olmayan, vaktin boşa harcandığı aktiviteler (trivial pursuit) olarak değerlendirmektedirler (North, 2006; Schug \& Niederjohn, 2008; Niederjohn, Schug \& Wood, 2013). Dersin öğreticileri (öğretmen/öğretim üyesi) ise kendi öğrencilerini suçlama yolunu tercih etmekte ve onları tarihsel konularda beceriksiz olmakla yargılamaktadırlar (Niederjohn, Schug \& Wood, 2013: 102).

Ekonomi etkin tarih öğretimi anlayışının eksik halkasıdır (Tokdemir, 2011). Haydar Kazgan'ın “Osmanlı'da Avrupa Finans Kapitali" başta olmak üzere Osmanlı’nın son yüzyılının çalkantılı döneminin ekonomik ve finansal yönden irdelendiği çalışmalarında vurguladığı tarihi olayları/kurumları ekonomi merkezli düşünme yaklaşımının tarih ders kitaplarına yansıtılması, bu eksik halkanın tamamlanmasında önemli bir adım olabilir. Lise başta olmak üzere farklı kademelerde tarih konularının etkin öğretiminde ekonomi merkezli düşünme yaklaşımını benimseyen "ekonomik düşünme biçimi (economic way of thinking)", ekonomiye ait temel kavramlarla entegre bir tarih anlatımının takip edilmesinde Haydar Kazgan'ın ekonomi ve finans tarihi bağlamında yürüttüğü çalışmalarında sunduğu analitik tarih yorumculuğu doğru bir hareket noktası olabilir.

| Kastamonu Eğitim Dergisi, 2020, Vol. 28, No. 3| 


\section{KAYNAKÇA}

Bowen, G. A. (2009). Document analysis as a qualitative research method. Qualitative Research Journal, 9(2), 27-40.

Corbin, J.M., ve Strauss, A. (2015). Basics of qualitative research: Techniques and procedures for developing grounded theory (4th ed.). Thousand Oaks, CA: Sage.

Çevik, A., Koç, G. ve Şerbetçi, K. (2019). Lise Türkiye Cumhuriyeti Inkılap Tarihi ve Atatürkçülük 12, Ders Kitabı, Devlet Kitapları 2. Baskı. Ankara: MEB.

Günçavdı, Ö. (2018). İstanbul Teknik Üniversitesinde İktisat Bilimi ve İktisat Eğitiminin Yüz Yılı, Efil Journal, 1 (1), 96-147.

Kazgan, H. (1985). Düyun-ı Umumiye. Tanzimat'tan Cumhuriyet'e Türkiye Ansiklopedisi (C. 3, ss. 691-716), İstanbul: iletişim.

Kazgan, H. 1995. Osmanlı'da Avrupa Finans Kapitali. İstanbul: Yapı Kredi.

Kazgan, H. (2005). Galata Bankerleri Cilt I, Ankara: Orion.

Kazgan, G. (2011). Prof. Dr. Haydar Kazgan ve Osmanlı Finans Tarihi. (Kolektif) Prof. Dr. Haydar Kazgan'a Armağan: Yakın Tarihimizin iktisadi Panoraması. Ankara: Türk Tarih Kurumu.

Niederjohn, M.S. Schug, M.C. \& Wood, W.C. (2013). The Case for Teaching Economics in American History: Assessment and the Economic Way of Thinking. Journal of Private Enterprise, 29 (1), 101-109.

North, D. (2006). Focus: Understanding Economics in U.S. History. New York: National Council on Economic Education.

Schug, M.C. \& Niederjohn, M.S. (2008). Can students learn economics in U.S. History Journal of Private Enterprise, 23 (2), $167-176$.

Tokdemir, E. (2011). Aykırı Bakışlar: Prof. Dr. Haydar Kazgan. (Kolektif) Prof. Dr. Haydar Kazgan'a Armağan: Yakın Tarihimizin iktisadi Panoraması. Ankara: Türk Tarih Kurumu.

Ulçenko, N. ve Kazgan, G. (2003). Dünden Bugüne Türkiye ve Rusya Politik Ekonomik ve Kültürel ilişkiler, (çev. Hakan Aksoy), İstanbul: İstanbul Bilgi Üniversitesi.

Yıldırım, A. ve Şimşek, H. (2013). Sosyal Bilimlerde Nitel Araştırma Yöntemleri. Ankara: Seçkin.

Yılmaz, A. (2019). Lise Tarih 10. Sınıf, Ders Kitabı, Ankara: İlke.

Yüksel E, vd. (2019a). Lise Tarih 10. Sınıf, Ders Kitabı, Devlet Kitapları 2. Baskı. Ankara: MEB.

Yüksel E, vd. (2019b). Lise Tarih 11. Sınıf, Ders Kitabı, Devlet Kitapları 1. Baskı. Ankara: MEB.

Çevik, A., Koç, G. ve Şerbetçi, K. (2019). Lise Türkiye Cumhuriyeti Inkılap Tarihi ve Atatürkçülük 12, Ders Kitabı, Devlet Kitapları 2. Baskı. Ankara: MEB. 